\title{
Biodiversity Status of the Immediate Vicinity of an Iron and Steel Recycling Factory in Ile-Ife, South-Western Nigeria
}

\author{
Oludare Oladipo AGBOOLA ${ }^{1 *}$, Olalekan Oluwatoyosi SALAMI ${ }^{2}$, Stephen OYEDEJI ${ }^{3}$
}

\author{
${ }^{1}$ Department of Botany, University of Lagos, Akoka, Yabaas, Nigeria; dipod2001@yahoo.com ( ${ }^{*}$ corresponding author) \\ ${ }^{2}$ Institute of Ecology and Environmental Studies, Obafemi Awolowo University, Ile-Ife, Nigeria; lekansalamio@gmail.com \\ ${ }^{3}$ Department of Plant Biology, University of Ilorin, Ilorin, Nigeria; princeseyed1st@yahoo.com
}

\begin{abstract}
Floristic composition of vegetation communities of 27 plots established along a line transect in the four major directions was investigated in the vicinity of an Iron and Steel factory in Ile-Ife, Nigeria. The aim of the study was to document the plant species composition (biodiversity) of the plant communities found within the $350 \mathrm{~m}$ perimeter of the facility in the study area, which will serve as a reference data, as there was no reported study for the area prior to the establishment of the factory. Plant species were identified to species level in a $10 \mathrm{x} 10 \mathrm{~m}$ plot and the occurrence of each species was described in semi-quantitative terms. The vegetation is heterogeneous in nature having 31 species of tree saplings and climbers, 26 of shrubs, 15 of herbaceous plants and 4 of grasses. These 107 plant species belong to forty six (46) plant families. The dominant families included Apocynaceae and Papilionaceae (9 species), Sapindaceae (8 species), Euphorbiaceae (6 species), Asteraceae, Cucurbitaceae, Malvaceae, Poaceae, Sterculiaceae and Verbenaceae (4 species). Among the diverse species recorded, Chromolaena odorata formed a ticket in almost all the plots. Other common species included Albizia zygia, Alchornea laxiflora, Aspilia africana, Cnestis ferruginea, Combretum sp., Icacina tricantha, Ipomoea involucrata, Momordica foetida, Panicum maximum, Paullinia pinnata, Simicrata welwitschii and Vigna gracilis. The index of similarity of the plots ranged from 6.1 to $71.8 \%$. The potential and vulnerability of the species were highlighted. Adherence to and enforcement of environmental regulations was recommended for preservation of the native species.
\end{abstract}

Keywords: environment, plant species, steel factory, vegetation studies

\section{Introduction}

The floristic resource of any country plays a vital role in human development and survival. All living organisms depends on vegetation resources either directly or indirectly as they supply food, timber, fuel, shade, shelter, organic manure and conserve soil fertility (Tukur et al., 2013). The Nigerian floral resource and biodiversity has been under threat from unsustainable agricultural land use, urbanization, industrialization and from other anthropogenic factors (Obute and Osuji, 2002). This has formed the inclusion of vegetation studies in the Environmental Impact Assessment report for the establishment of major industries. This is done with a view to protect, manage and restore genetic resources for sustainable development despite the need for human development. Such studies does not only document occurrence of such species, but also usually provide measures of preservation of native species especially if rare. Vegetation studies are undertaken all over the world to document the notable floral diversity of the different localities.

Some researchers had carried out a lot of work to determine and document properties and uses of various indigenous plants in Nigeria. Bhat et al. (1990) documented the ethnobotanical survey of different plant resource in Kwara State of Nigeria. Nwosu (2002) also studied southern Nigeria pteridophytes, while Ibe and Nwufo (2005) reported the medicinal plants of the South-eastern Nigeria; Ubom (2010) gave the ethnobotanical biodiversity inventory of the plant resources in the Niger Delta area of Nigeria. Other studies of places that are potentially rich in plant species, but under threat due to urban development, are being studied. Soladoye et al. (2005) made an extensive study of the angiosperm community of the permanent site of Olabisi Onabanjo University with the aim of conserving them for posterity. Also, Durugbo et al. (2012) made a comprehensive vegetation inventory of the Redemption Camp (the headquarters of the Redeemed Christian Church of God) where the temporary site of its university is located, and emphasized some strategies for conservation.

The objective of this research was to document the floral component of the vicinity of the factory with a view to determining its floristic composition and similarity and to determine the state biodiversity erosion due to anthropogenic disturbances.

\section{Materials and methods}

\section{The study area}

The study was conducted in Ile-Ife, Southwest Nigeria on latitude $7^{\circ} 29^{\prime \prime} \mathrm{N}$ and longitude $4^{\circ} 28^{\prime \prime} \quad \mathrm{E}$. It is located along Ife-Ibadan expressway about $4 \mathrm{~km}$ from Ife Central Local 
Government Secretariat and about $5 \mathrm{~km}$ from the Obafemi Awolowo University (OAU) main campus. Ile-Ife is situated within the rainforest zone and the climate is identified to be humid tropical climate characterized by two prominent seasons: the rainy and the dry season (Olajuyigbe et al., 2012). The dry season is short, usually lasting from November to March, and the longer rainy season prevails during the remaining months usually with two peaks, one in July and the other in September. The weather report from the meteorological stations located within OAU Teaching and Research farm showed the annual rainfall at Ile-Ife averaged $1400 \mathrm{~mm} \mathrm{yr}^{-1}$ in a 5-year survey (Oke and Isichei, 1997) and mean annual temperature ranges from 28 to $34^{\circ} \mathrm{C}$ (Olajuyigbe et al., 2012).

\section{Sampling procedure}

Data were collected from 27 sample plots of $10 \times 10 \mathrm{~m}$, laid along a line transect of $50 \mathrm{~m}$ distance from the fence of the steel recycling factory in order to capture, as close as possible, the native species of the factory location prior to establishment. The transects were laid along the four cardinal directions of North, East, South and West of the factory up to three hundred and fifty meters in each of the four directions. The total enumeration was done for two weeks between late January and early February (dry season). Within each sampling plot, the plants were identified to species level and the occurrences of the each species were recorded in each plot. Those that cannot be identified at the field were taken to IFE Herbarium for proper identification. Specimens of the plants species were collected from the study site and pressed. Identification, authentication and classification of the plant species into families was carried out in the Department of Botany Herbarium (IFE), Obafemi Awolowo University, IleIfe.

The occurrence of each species was described in semiquantitative terms in accordance with the method used by Edwin-Wosu and Edu (2013). Species with a wide frequency of distribution with many stands within a plot and across majority of plots are described as very abundant $(++++)$. Some species with similarly wide frequency of distribution, but with few stands are said to be less frequent or abundant $(+++)$, while species of limited geographical distribution and with a few stands are termed scarce $(++)$ and very scarce $(+)$ species.

The index of similarity (I. S.) of the 27 plots studied was calculated using the coefficient of similarity by Sorenson (1948):

$$
\text { I. S. }=\frac{2 C}{A+B} x 100
$$

where $\mathrm{C}=$ the number of species common to the two plots compared;

$$
A=\text { number of species in plot } A \text {; }
$$$$
\mathrm{B}=\text { number of species in plot } \mathrm{B} \text {. }
$$

\section{Results and discussions}

A total of 107 plant species belonging to 46 plant families were recorded in the floristic survey of the study area (Table 1) in which twenty one families were prevalently dominant, with two or more species. Among the dominant families, Apocynaceae and Papilionaceae had the highest species diversity in terms of richness with nine species. Other families recorded include Sapindaceae (8 species), Euphorbiaceae (6 species), Asteraceae, Cucurbitaceae, Malvaceae, Poaceae,
Sterculiaceae, Verbenaceae (4 species), Combretaceae, Mimosaceae, Moraceae, Rubiaceae (3 species), Bignomiaceae, Caesalpiniaceae, Connaraceae, Convolvulaceae, Musaceae, Smilacaceae and Tiliaceae ( 2 species) respectively. The Nigeria rainforest belt is dominated by members of the families represented in the study area which agrees with the findings of Isichei (1995), Soladoye et al. (2005), Durugbo et al. (2012). In terms of species diversity, the study area recorded some variations in richness and evenness although Chromolaena odorata formed a ticket in almost all the plots. Other common species included Albizia zygia, Alchornea laxiflora, Aspilia africana, Cnestis ferruginea, Combretum sp., Icacina tricantha, Ipomoea involucrata, Momordica foetida, Panicum maximum, Paullinia pinnata, Simicrata welwitschii, Vigna gracilis and some cultivated Manihot esculenta (Table 2). The presence and dominance of Chromolaena odorata (an early colonizer of waste land), other early succession species and tree samplings indicate previous general disturbances (Hall and Okali, 1979).

In terms of habit and life form, there was a domination of trees and climbers with a representative total of 31 species each; twenty-six (26) were recorded as shrubs, fifteen (15) as herbs and four (4) of the grass family. The frequency and percentage of the life forms encountered in this study is presented in Table 3. The domination of trees (which were all saplings) and climbers, both representing $58 \%$ within the study area, is an indication of a regeneration process of secondary vegetation structure.

Hence, results showed that the vegetation in the area is more of a rich, diverse and heterogeneous nature with a mixture of various life forms involving trees, shrubs, herbs and climbers, characterized by both natural and anthropogenic influences. This is attributed to processes such as the influence of human activities (farming and constructions, soil removal), regeneration, as well as seasonal variation influenced by local environmental conditions (Edwin-Wosu and Edu, 2013). These had affected the vegetation structure in terms of species abundance and diversity.

This corroborates the affirmation of Offiong et al. (2012) that human activity is an important agent influencing plant species biodiversity.

The level of similarity was generally lower than $50 \%$ as observed in the standing vegetation of the plots using the similarity analysis. This is a reflection of the difference in species composition of the plots. Indices of similarity of each pair of plots are shown in Table 4. The highest variation (93.9) was observed between plot south $350 \mathrm{~m}$ and plot west $350 \mathrm{~m}$, while the level of variation of 28.2 was the lowest, between south 100 $\mathrm{m}$ and south $200 \mathrm{~m}$ plots, possibly because of closeness of the two areas.

Out of the 46 families encountered in this study, 32 representing $70 \%$ had one or two species representation due to several anthropogenic activities. These activities portends grave danger to plant species losses occurring as a result of direct human activities (such as farming and soil collection for construction purposes) and fragmentation of the ecosystem from continued land development. This is because some of the plants species encountered in this study have been documented to have medicinal properties in the studies of Chima et al. (2013), Oni (2010). Some of these plants especially Panicum maximum, Sida acuta, Chromolaena odorata, Aspilia Africana, Andropogon gayanus have also been reported to be tolerant to metal pollution around metal based 
Table 1. Species distribution according to families

\begin{tabular}{|c|c|c|}
\hline S/No & Families & No. of Species \\
\hline 1 & Acanthaceae & 1 \\
\hline 2 & Amaranthaceae & 1 \\
\hline 3 & Anacardiaceae & 1 \\
\hline 4 & Apocynaceae & 9 \\
\hline 5 & Araceae & 1 \\
\hline 6 & Asteraceae & 4 \\
\hline 7 & Bignomiaceae & 2 \\
\hline 8 & Caesalpiniaceae & 2 \\
\hline 9 & Cannaceae & 1 \\
\hline 10 & Capparidaceae & 1 \\
\hline 11 & Caricaceae & 1 \\
\hline 12 & Celastraceae & 1 \\
\hline 13 & Combretaceae & 3 \\
\hline 14 & Commelinaceae & 1 \\
\hline 15 & Connaraceae & 2 \\
\hline 16 & Convolvulaceae & 2 \\
\hline 17 & Cucurbitaceae & 4 \\
\hline 18 & Dioscoreaceae & 1 \\
\hline 19 & Ebenaceae & 1 \\
\hline 20 & Euphorbiaceae & 6 \\
\hline 21 & Icacinaceae & 1 \\
\hline 22 & Lauraceae & 1 \\
\hline 23 & Lecythidaceae & 1 \\
\hline 24 & Loganiaceae & 1 \\
\hline 25 & Malvaceae & 4 \\
\hline 26 & Melastomataceae & 1 \\
\hline 27 & Meliaceae & 1 \\
\hline 28 & Mimosaceae & 3 \\
\hline 29 & Menispermaceae & 1 \\
\hline 30 & Moraceae & 3 \\
\hline 31 & Musaceae & 2 \\
\hline 32 & Myrtaceae & 1 \\
\hline 33 & Palmae (Arecaceae) & 1 \\
\hline 34 & Papilionaceae & 9 \\
\hline 35 & Periplocaceae & 1 \\
\hline 36 & Passifloraceae & 1 \\
\hline 37 & Poaceae(Gramineae) & 4 \\
\hline 38 & Rubiaceae & 3 \\
\hline 39 & Sapindaceae & 8 \\
\hline 40 & Smilacaceae & 2 \\
\hline 41 & Solanaceae & 1 \\
\hline 42 & Sterculiaceae & 4 \\
\hline 43 & Tiliaceae & 2 \\
\hline 44 & Ulmaceae & 1 \\
\hline 45 & Verbenaceae & 4 \\
\hline \multirow[t]{2}{*}{46} & Vitaceae & 1 \\
\hline & Total & 107 \\
\hline
\end{tabular}


Table 2. Occurrence and status of the plant species in the of study area

\begin{tabular}{|c|c|c|c|c|c|}
\hline $\mathrm{S} / \mathrm{N}$ & Plant Species & Family & Habit & Number of plot(s) found & Remarks \\
\hline 1 & Abelmoschus esculentus & Malvaceae & Herb & 1 & + \\
\hline 2 & Adenia lobata & Passifloraceae & Climber & 1 & + \\
\hline 3 & Albizia adianthifolia & Mimosaceae & Tree & 2 & + \\
\hline 4 & Albizia zygia & Mimosaceae & Tree & 17 & ++++ \\
\hline 5 & Alchornea cordifolia & Euphorbiaceae & Tree & 3 & ++ \\
\hline 6 & Alchornea laxiflora & Euphorbiaceae & Shrub & 14 & ++++ \\
\hline 7 & Allophylus africanus & Sapindaceae & Shrub & 2 & + \\
\hline 8 & Andropogon gayanus & Poaceae & Grass & 2 & ++ \\
\hline 9 & Anthocleista nobilis & Loganiaceae & Tree & 1 & + \\
\hline 10 & Antiaris africana & Moraceae & Tree & 7 & +++ \\
\hline 11 & Aspilia africana & Asteraceae & Herb & 13 & ++++ \\
\hline 12 & Asystasia gangetica & Acanthaceae & Herb & 10 & +++ \\
\hline 13 & Baissea breviloba & Apocynaceae & Climber & 1 & ++ \\
\hline 14 & Baphia nitida & Papilionaceae & Shrub & 3 & + \\
\hline 15 & Blighia sapida & Sapindaceae & Tree & 3 & + \\
\hline 16 & Blighia unijugata & Sapindaceae & Tree & 1 & + \\
\hline 17 & Callichilia monopodialis & Apocynaceae & Shrub & 1 & + \\
\hline 18 & Calopogonium mucunoides & Papilionaceae & Climber & 3 & ++ \\
\hline 19 & Canna indica & Cannaceae & Herb & 2 & ++ \\
\hline 20 & Cardiospermum grandiflorum & Sapindaceae & Climber & 1 & + \\
\hline 21 & Cardiospermum halicacabum & Sapindaceae & Climber & 1 & + \\
\hline 22 & Carica papaya & Caricaceae & Tree & 3 & + \\
\hline 23 & Cassytha filiformis & Lauraceae & Climber & 1 & + \\
\hline 24 & Castanola sp. & Connaraceae & Shrub & 2 & + \\
\hline 25 & Chassalia kolly & Rubiaceae & Shrub & 3 & ++ \\
\hline 26 & Chromolaena odorata & Asteraceae & Shrub & 26 & ++++ \\
\hline 27 & Cissampelos owariensis & Menispermaceae & Climber & 2 & + \\
\hline 28 & Cissus sp. & Vitaceae & Climber & 1 & + \\
\hline 29 & Clerodendrum sp. & Verbenaceae & Climber & 6 & +++ \\
\hline 30 & Clerodendrum volubile & Verbenaceae & Climber & 4 & ++ \\
\hline 31 & Cnestis ferruginea & Connaraceae & Shrub & 11 & ++++ \\
\hline 32 & Cola nitida & Sterculiaceae & Tree & 1 & + \\
\hline 33 & Combretum platypterum & Combretaceae & Climber & 6 & ++ \\
\hline 34 & Combretum racemosum & Combretaceae & Climber & 4 & ++ \\
\hline 35 & Combretum sp. & Combretaceae & Climber & 11 & ++++ \\
\hline 36 & Commelina sp. & Commelinaceae & Herb & 1 & + \\
\hline 37 & Cucurbita sp. & Cucurbitaceae & Climber & 1 & + \\
\hline 38 & Cyathula sp. & Amaranthaceae & Herb & 1 & + \\
\hline 39 & Dalbergia lacteal & Papilionaceae & Shrub & 1 & + \\
\hline 40 & Deinbollia pinnata & Sapindaceae & Shrub & 1 & + \\
\hline 41 & Desmodium ramosissimum & Papilionaceae & Herb & 1 & + \\
\hline 42 & Dioscorea sp. & Dioscoreaceae & Climber & 1 & + \\
\hline 43 & Diospyros monbuttensis & Ebenaceae & Tree & 1 & + \\
\hline 44 & Elaeis guineensis & Arecaceae & Tree & 3 & + \\
\hline 45 & Ficus exasperate & Moraceae & Tree & 3 & + \\
\hline 46 & Ficus sur & Moraceae & Tree & 8 & ++ \\
\hline 47 & Flueggea virosa & Euphorbiaceae & Shrub & 5 & ++ \\
\hline 48 & Funtamia elastic & Apocynaceae & Tree & 1 & + \\
\hline 49 & Gliricidia sepium & Papilionaceae & Tree & 1 & + \\
\hline 50 & Glyphaea brevis & Tiliaceae & Shrub & 1 & + \\
\hline 51 & Hedranthera barteri & Apocynaceae & Shrub & 3 & + \\
\hline 52 & Holarrhen a floribunda & Apocynaceae & Tree & 8 & ++ \\
\hline 53 & Icacina tricantha & Icacinaceae & Herb & 12 & ++++ \\
\hline 54 & Ipomoea involucrate & Convolvulaceae & Climber & 17 & ++++ \\
\hline 55 & Lagenaria breviflora & Cucurbitaceae & Climber & 1 & + \\
\hline 56 & Landolphia sp. & Apocynaceae & Climber & 1 & + \\
\hline 57 & Lantana camara & Verbenaceae & Shrub & 1 & + \\
\hline
\end{tabular}


49

\begin{tabular}{|c|c|c|c|c|c|}
\hline 58 & Lecaniodiscus cupanioides & Sapindaceae & Tree & 6 & ++ \\
\hline 59 & Leptoderis micrantha & Papilionaceae & Climber & 3 & ++ \\
\hline 60 & Leucaena leucocephala & Mimosaceae & Shrub & 4 & ++ \\
\hline 61 & Lonchocarpus cyanescens & Papilionaceae & Shrub & 2 & + \\
\hline 62 & Mallotus oppositifolius & Euphorbiaceae & Shrub & 1 & + \\
\hline 63 & Mangifera indica & Anacardiaceae & Tree & 1 & + \\
\hline 64 & Manibot esculenta & Euphorbiaceae & Shrub & 11 & ++++ \\
\hline 65 & Margaritaria discoidea & Euphorbiaceae & Tree & 1 & + \\
\hline 66 & Markhamia tomentosa & Bignomiaceae & Tree & 3 & + \\
\hline 67 & Melanthera scandens & Asteraceae & Herb & 2 & + \\
\hline 68 & Memecylon Linn. & Melastomataceae & Shrub & 1 & + \\
\hline 69 & Merremia sp. & Convolvulaceae & Climber & 1 & + \\
\hline 70 & Mezoneuron benthamianum & Caesalpiniaceae & Climber & 6 & ++ \\
\hline 71 & Momordica charantia & Cucurbitaceae & Climber & 4 & ++ \\
\hline 72 & Momordica foetida & Cucurbitaceae & Climber & 9 & ++++ \\
\hline 73 & Morinda lucida & Rubiaceae & Tree & 1 & + \\
\hline 74 & Mucuna pruriens & Papilionaceae & Herb & 1 & + \\
\hline 75 & Musa paradisiacal & Musaceae & Tree & 1 & + \\
\hline 76 & Musa sapientum & Musaceae & Tree & 1 & + \\
\hline 77 & Napoleona imperialis & Lecythidaceae & Shrub & 2 & + \\
\hline 78 & Newbouldia laevis & Bignomiaceae & Tree & 7 & ++ \\
\hline 79 & Panicum maximum & Poaceae & Grass & 8 & ++++ \\
\hline 80 & Parquetina nigrescens & Periplocaceae & Climber & 1 & + \\
\hline 81 & Paullinia pinnata & Sapindaceae & Climber & 9 & ++++ \\
\hline 82 & Pleioceras barteri & Apocynaceae & Shrub & 1 & + \\
\hline 83 & Psidium guajava & Myrtaceae & Shrub & 1 & + \\
\hline 84 & Rauvolfia vomitoria & Apocynaceae & Tree & 2 & + \\
\hline 85 & Ritchiea longipedicellata & Capparidaceae & Climber & 2 & + \\
\hline 86 & Sarcocephalus latifolius & Rubiaceae & Climber & 1 & + \\
\hline 87 & Senna siamea & Caesalpiniaceae & Tree & 3 & + \\
\hline 88 & Setaria barbata & Poaceae & Grass & 1 & + \\
\hline 89 & Sida acuta & Malvaceae & Herb & 8 & +++ \\
\hline 90 & Sida spinosa & Malvaceae & Herb & 1 & + \\
\hline 91 & Simicrata welwitschii & Celastraceae & Climber & 13 & ++++ \\
\hline 92 & Smilax kraussiana & Smilacaceae & Climber & 3 & + \\
\hline 93 & Solanum torvum & Solanaceae & Shrub & 5 & ++ \\
\hline 94 & Stachytarpheta cayennensis & Verbenaceae & Herb & 1 & + \\
\hline 95 & Sterculia tragacantha & Sterculiaceae & Tree & 1 & + \\
\hline 96 & Theobroma cacao & Sterculiaceae & Tree & 2 & + \\
\hline 97 & Tithonia diversifolia & Asteraceae & Shrub & 8 & +++ \\
\hline 98 & Trema orientalis & Ulmaceae & Tree & 3 & + \\
\hline 99 & Trichilia prieureana & Meliaceae & Tree & 2 & + \\
\hline 100 & Triclisia subcordata & Smilacaceae & Climber & 4 & ++ \\
\hline 101 & Triumfetta cordifolia & Tiliaceae & Shrub & 1 & + \\
\hline 102 & Urena lobata & Malvaceae & Herb & 1 & + \\
\hline 103 & Vigna gracilis & Papilionaceae & Climber & 13 & ++++ \\
\hline 104 & Voacanga africana & Apocynaceae & Tree & 1 & + \\
\hline 105 & Waltheria indica & Sterculiaceae & Shrub & 1 & + \\
\hline 106 & Xanthosoma mafaffa & Araceae & Herb & 2 & + \\
\hline 107 & Zea mays & Poaceae & Grass & 3 & ++ \\
\hline
\end{tabular}

Note: $+=$ Very scarce; $++=$ Scarce; $+++=$ Abundant; $++++=$ Very abundant

industries in the works of Anoliefo et al. (2008) and have been listed as candidates for potential phyto-remediation of heavy metal contaminated soils subject to further studies.

In view of the potential of the species identified in the study area and the fact that majority $(70 \%)$ are vulnerable for elimination because of their limited number in representation and occurrence (having $\leq 2$ species or occurring in $\leq 2$ plots), government should enforce that the provisions of
Table 3. The frequency and percentage of the plant life form of the study

\begin{tabular}{ccc}
\hline Plant Forms & Frequency & Percentage \\
\hline Trees & 31 & 29 \\
Shrubs & 26 & 24 \\
Herbs & 15 & 14 \\
Grass & 4 & 4 \\
Climber & 31 & 29 \\
\hline
\end{tabular}


51

Environmental Impact Assessment reports is strictly adhered to. These include among other things, compensatory planting and restocking of indigenous species, provision of new appropriate habitat and careful timing of major disturbances.

\section{Conclusions}

The findings of the present study provides a complete view of the floristic composition of the study area, which is rich in regenerating species that could result in the establishment of a diverse natural forest if protected to conserve the saplings of the regenerating species. However, since this previously forested area seems to have been opened up for development (potentially into industrial and residential estates), the importance of preserving the threatened diversity and available plant forms in the area cannot be overemphasized. Government, industries and individuals must abide by the provisions of the EIA act in further development of the vicinity.

\section{Acknowledgments}

We appreciate Mr. G. Ibanesebhor and B. Omomoh of Ife Herbarium in the technical assistance in the identification, collection and pressing of the plant species and specimens. We are also thankful to B. Jimba, A. Adetokun and A. Adeniyi for their dedicated field support.

\section{References}

Anoliefo GO, Ikhajiagbe B, Okonokhua BO, Edegbai BO, Obasuyi DC (2008). Metal tolerant species distribution and richness in and around the metal based industries: Possible candidates for phytoremediation. African J Environm Sci Technol 2(11):360370.

Bhat RB, Etejere EO, Oladipo VT (1990). Ethnobotanical studies from Central Nigeria. Economic Botany, 44:382-390.

Chima UD, Ofodile EAU, Okorie MCF (2013). A survey of plants used in the treatment of ante-natal and post-natal disorders in Nneochi Local Government area of Abia State, Nigeria. Greener J Bio Sci3(6):229-237.

Durugbo EU, Oyetoran BO, Oyejide NE (2012). Vegetation inventory of the Redemption Camp, Ogun State, Nigeria; Evaluation of medicinal plant resources and strategies for Conservation. J Biol Sci 12(1):34-42.

Edwin-Wosu NL, Edu EAB (2013). Eco-taxonomic assessment of plant species regeneration status in a postremediated crude oil impacted site in parts of Ibibio-I-Oil field in Ikot-Ada Udo, IkotAbasi local government area of Akwa Ibom State, Nigeria. Asian J Plant Sci Res 3(3):14-23.
Hall JB, Okali DUU (1979). A structural and floristic analysis of woody fallow vegetation near Ibadan, Nigeria. Nigerian J Ecol 67:321-346.

Ibe AE, Nwufo MI (2005). Identification, collection and domestication of medicinal plants in Southeastern Nigeria. Africa Development 30(3):66-77.

Isichei AO (1995). Omo biosphere reserve, current status, utilisation of biological resources and sustainable management. UNESCO South-South cooperation programme, $11-48 \mathrm{p}$.

Nwosu MO (2002). Ethnobotanical studies on some pteridophytes of Southern Nigeria. Econom Bot, 56(3):255-259.

Obute GC, Osuji LC (2002). Environmental awareness and dividends: A scientific discourse. Afr J Interdisciplin Stud 3:90-94.

Olajuyigbe AE, Alinaitwe P, Adegboyega SA, Salubi E (2012) Spatial analysis of factors responsible for incidence of water borne diseases in Ile-Ife, Nigeria. Journal of Sustainable Society 1(4):96-113.

Offiong RA, Iwara AI, Njar GN, Atu JE (2012). Effects of industrial activities on the structure and floristic pattern of vegetation within the calabar port authority, SouthSouthern Nigeria. J Geog Geol 4(1):203-211.

Oke SO, Isichei AO (1997). Floristic composition and structure of the fallow vegetation in Ile- Ife Area of South Western Nigeria. Nigerian J Bot 10:37-50.

Oni PI (2010). Ethnobotanical survey of a fallow plot for medicinal plants diversity in Idena village Ijebu-Ode, South-western Nigeria. J Med Plants Res 4(7):509-516.

Sorenson T (1948). A method of establishing groups of equal amplitude in a Plant society based on similarity of species content. K. Danske Vidensk Selsk 5:1-34.

Soladoye MO, Sonibare MA, Nadi AO, Alabi DA (2005). Indigenous Angiosperm biodiversity of Olabisi Onabanjo University permanent site. African J Biotechnol 4 (5):554562.

Tukur R, Adamu GK, Abdulrashid I, Rabi'u M (2013). Indigenous Trees Inventory And Their Multipurpose Uses In Dutsin-Ma Area Katsina State. European Sci J 9(11):288-300.

Ubom RM (2010). Ethnobotany and biodiversity conservation in the Niger Delta, Nigeria. Intern J Bot 6:310-322. 